\title{
Speaking for the Arabian Subaltern; \\ Latent Orientalism in Eldon Rutter's Journey to Mecca
}

\author{
Antar Abdellah \\ South Valley University, Egypt \\ Solhyabdallah99@gmail.com
}

\begin{abstract}
The study reviews Eldon Rutter's book "the two cities of Arabia" and makes a textual analysis of selected excerpts. Rutter's book has long been praised for its objective tone in dealing with Islam and reporting on the religious rituals he witnessed and participated in while he was visiting Mecca in disguise as a Muslim pilgrim in the early $20^{\text {th }}$ century. This study argues that while Rutter's account does not seem to be biased against the Arabs and Muslims, there are certain instances of latent orientalism throughout his account. Said's Orientalism and Spivak's Subaltern are the main theoretical concepts against which the analysis and discussion are carried out. The study then compares between Rutter's orientalism and present-day orientalism in dealing with the image of Arabs and Muslims in the media.
\end{abstract}

Keywords: Orientalism, Subaltern, Rutter, Arabs, Muslims, Islam, Hegemony, power, Media, Othering.

\section{Introduction:}

In 1925, the English orientalist Eldon Rutter decided to visit the two holy cities of Arabia despite the dangerous circumstances during the aftermath of WWI and the turbulence in the Middle East. Rutter's motive was to follow the steps of very few orientalists who could make it to the forbidden cities of Mecca and Madinah. He travelled alone in disguise under the name of Haj Ahmed and pretended he was a Muslim pilgrim and merchant form Syria. His Arabic was perfect, and his knowledge about Islam was profound. Both qualities made it easy for him to go through this dangerous journey. Upon return, Rutter wrote about his journey in a book ${ }^{1}$ of two volumes

\footnotetext{
${ }^{1}$ Eldon Rutter. The Holy Cities of Arabia. (London and New York. Putnam's sons. 1928).
} 
entitled: The Two Holy Cities of Arabia. While a big part of the book is dedicated to the account on Mecca, a brief part is allocated for his journey to Madinah.

This study seeks to analyze how Rutter saw the people in Madinah, how he interpreted the different rituals, symbols and myths regarding the practices of Islamic faith at that time and how his western attitude was manifested in his description. My argument is that although Rutter seems to have honoured Islam and Muslims, and although his descriptions provide a great source of historical evidence from that time, instances of latent Orientalism can be traced. Orientalism, in this context, means the West's inherent inclination to superiority and handling the Other, Muslim and Arabia in this case, as timeless, exotic, inferior, uncivilized and in need of European help. I will be drawing on the works of Edward Said- mainly Orientalism ${ }^{2}$, Orientalism Reconsidered ${ }^{3}$ and Covering Islam", and Gayatri Spivak - mainly her article "can the subaltern speak?" ${ }^{4}$. Other philosophers who are also important but not the main basis of argument include Foucault's power relation concepts ${ }^{6}$ and Gramsci's concept of hegemony. ${ }^{7}$ The study will start with an introduction about Eldon Rutter and his background, including an overview of the orientalist discourse of journeys to Mecca. The analysis part will include extracts from Rutter's book with critical commentary. The focus would be on extracts representing religious practices as social phenomena and how Rutter represented them. In my analysis, I will be drawing on David Spurr's technique

\footnotetext{
${ }^{2}$ Edward Said. Orientalism. (Vintage Books. 1994).

${ }^{3}$ Edward Said. Orientalism Reconsidered. Cultural Critique, No. 1 (Autumn, 1985), pp. 89-107

${ }^{4}$ Edward Said, Covering Islam: How the Media and the Experts Determine How We See the Rest of the World. (Vintage Books. 1997).

${ }^{5}$ Gayatri Chakravorty Spivak, "Can the Subaltern Speak?”. In The post-colonial studies reader. Edited by Ashcroft, Bill, Gareth Griffiths, and Helen Tiffin, eds. (Taylor \& Francis, 2006).

6 Gary Gutting, ed. The Cambridge Companion to Foucault. (Cambridge University Press, 2005).

${ }^{7}$ Hagai Katz, "Gramsci, hegemony, and global civil society networks." Voluntas: International Journal of Voluntary and Nonprofit Organizations 17, no. 4 (2006): 332-347.
} 
for locating colonial discourse ${ }^{8}$. The last section will draw concluding remarks on the latent orientalist on present-day Arabia and Islam as compared to Rutter's view 100 years ago.

\section{Part I: Eldon Rutter; life, Journey and the discourse of orientalist Hajj}

Eldon Rutter may be the most obscure English Orientalist, and his book may be the most neglected, though most valuable, among Orientalist literature on journeys to Mecca. Very little is known about his life and career. Gilham in a recent review of Rutter's book says "In fact, Rutter's life was clouded in mystery and he reveals almost nothing about himself in this very long book. Upon reading it in 1928, T.E. Lawrence wrote "I wonder who he is? Some very queer fish, probably." Drawing on thorough biographical research and with unique access to previously unpublished family papers, Facey and Sharpe - who wrote an introduction to the reprint of Rutter's book in 2015- show that Rutter is still enigmatic (he was born Clement Edward, not Eldon, in 1894), who was thrust into the spotlight upon publication of the Holy Cities in 1928 and quickly slipped back into obscurity.

All that is known about Rutter is that he was born in 1894, in Camberwell. The premature death of his father obliged him to leave school at 16 . Shipman ${ }^{9}$ explains how Rutter's military service as a trooper during World War 1 took him to Egypt, Palestine and Gallipoli (where he was wounded). After the war, he spent nearly four years working for Nestle in Penang, Malaya, where he learned Arabic from Hadhrami immigrants and is believed to have formally converted to Islam. After his return from the Far East in 1924, he spent a year in Egypt studying the theology of his adopted faith in preparation for his pilgrimage to Mecca and Medina in 1925/1926. He visited Arabia at a

\footnotetext{
${ }^{8}$ David Spurr, "The Rhetoric of Empire: Colonial Discourse in Journalism, travel writing and imperial administration. (Duke University Press. 1993).

${ }^{9}$ John Shipman, "Eldon Rutter. The Holy Cities of Arabia." Book Review. Asian Affairs, 47:1, 141-143, DOI:

10.1080/03068374.2016.1130966 (2016): 141-143.
} 
critical juncture. Hijaz was in turmoil due to the incursions of the Wahhabis, otherwise known as the 'Ikhwan', a fanatically puritan sect of Islam. Mecca had fallen to them and Medina was under siege. The capitulation of Jedda completed the overthrow of Hashemite rule in the Hijaz. Under Wahhabi occupation a foreigner risked denunciation as a spy and death. The German Orientalist Schacht ${ }^{10}$ valued Rutter's account of Arabia as "the first authentic testimony to the status of the Hejaz immediately after the Wahhabai conquest. When the author departed from Egypt, Jiddah and Medina were still in Hashimite hands, so that he had to make his way to Mecca by a more rarely used route". Shipman claims he was "the first Westerner to witness the wave of wanton destruction perpetrated by the Wahhabis during and after their recent siege of the [Taif] city". So, Rutter was writing about key events that he witnessed firsthand and was documenting a precious piece of reference. Shipman laments the short life of Rutter and the negligence of his exceptional book; "The book is a treasure house of descriptive writing, social anthropology, Islamic history and scholarship". (p.141).

Due to the mysterious life Rutter led, many critics were not sure whether he was a Christian or a devoted Muslim convert, including his own wife ${ }^{11}$. Whether he was a Muslim or not, Rutter's book represents a treasure of records on the practices of religion in Mecca during a time of turmoil. Schacht (1930) states "The most valuable scientific side of the book is, as already indicated, the presentation of the immediate consequences of the Wahhabai conquest. Here is the essentially unchanged continuation of the Meccan life, the description of which in detail contains many chapters cleverly interspersed in the actual travelogue” (p. 214). Hamilton Gibb says: "Rutter's

\footnotetext{
${ }^{10}$ Joseph Schacht. "Eldon Rutter: The Holy Cities of Arabia”. Book review. Journal Orientalistische Literaturzeitung; Jan 1, 1930; 33, Periodicals Archive Online pg. 213

${ }^{11}$ We will not discuss this issue as it is outside of the scope of this paper. For detailed discussion of Rutter's creed, refer to introduction to the Arabic translation of Rutter's book, published in Mecca in 2014.
} 
book is possibly the best Introduction to Arabia ever written"(p. 625 $\left.5^{12}\right)$. Despite its uniqueness, this was Rutter's only book. After the Second World War, he led a peripatetic life estranged from his family; it is not known how, when, or where he died.

Rutter's book comes from within a tradition of Orientalist discourse that attempted to penetrate the forbidden cities of Mecca and Madinah. Michael Wolfe ${ }^{13}$ traces the historical attempts to enter Mecca by adventurers from the West, from the account of Ludovico di Varthema in 1503 to his own journey by plane in 1990 . He points out that the discourse of journey to Mecca has long been inconsistent, sometimes biased, and mostly shocking. "The tale of the Hajj is not always a simple one. Its administration through the years has been in the hands and sometimes at the mercy of many a facile potentate, and the cynicism with which it has been manipulated as a symbol can be shocking". (p. xi) However, for Rutter, Wolfe states that his account was one of the most reliable and truly detailed with no clear prejudice.

\section{Part II: Latent orientalist instances}

Orientalism, according to Edward Said, is not

a mere political subject matter or field that is reflected passively by culture, scholarship, or institutions; nor is it a large and diffuse collection of texts about the Orient; nor is it representative and expressive of some nefarious "Western" imperialist plot to hold down the "Oriental" world". Rather, it is a discourse that "is produced and exists in an uneven exchange with

\footnotetext{
${ }^{12}$ Hamilton A. R. Gibb, Review of The Holy Cities of Arabia by Eldon Rutter, Bulletin of the School of Oriental and African Studies, 5 (1929), p. 625

13 Michael Wolfe. One Thousand Roads to Mecca: Ten Centuries of Travelers Writing about the Muslim Pilgrimage. (New York: Grove Press. 1997), p. xi.
} 
various kinds of power, shaped to a degree by the exchange with power or intellectual power ${ }^{14}$.

Orientalism simply represents "a considerable dimension of modern political-intellectual culture, and as such has less to do with the Orient than it does with "our" [western] world". While instances of Orientalism can be clearly manifested in political accounts by people like Cromer and Curzon, latent orientalist is not easy to sort out, as it is mostly enclosed in objective treatments of the Other.

Othering for, Spivak, is "an ideological process that isolates groups that are seen as different from the norm of the colonizers" ${ }^{\prime 15}$. For Spivak, othering is the way in which imperial discourse creates colonized, subaltern subjects. Like Edward Said, she views othering dialectically: the colonizing subject is created in the same moment as the subaltern subject. In this sense, othering expresses a hierarchical, unequal relationship. In Rutter's book, we have the following extracts that represent different types of latent orientalist discourse.

The dwellers in this terrible region are of the tribe of Curaysh--that strange confraternity which numbers among its families the noblest of the Arabs and also the vilest. Among them, said Ali, are the Beni Da'd and the Beni Fahm, .. he told me of their gruesome method of circumcision. Among them, said he, this rite is deferred until the subject reaches the age of puberty. Before he reaches that age, the youth's parents have already arranged his marriage contract. On the day appointed, the elders of the two families assemble for the purpose of witnessing the performance of the Semitic rite. The youth's affianced bride is also present. ...the skin of the whole belly

14 Supra, not 2, p. 12.

${ }^{15}$ William Deal and Timothy Beal. Theory for religious studies. (Routledge, 2004). 
from immediately below the navel, is removed, as is also that of the front

and inner side of the thighs for halfway to the knees, and the whole of the

skin of the male organ. (vol 2, p. 56)

The description of this unimaginable rite of circumcision of the tribes of Fahm and $\mathrm{Da}$ 'd is absolutely wrong. No such experience exists according to people from these tribunes themselves ${ }^{16}$ if we imagine that a person can make it alive with no sedation. What is more important, however, is how Rutter links this brutal practice to religion and Semitism. In having two pages for the description of a proposed ritual that he does not witness, Rutter is latently using the discourse of exoticism ${ }^{17}$ that is common in the Orientalist's' writings of religious practices of non-Europeans, whether Arabs, Asians or Indigenous. Charles Long (2004) ${ }^{18}$ points out how Henri Baudet's Paradise on Earth has the subtitle Some Thoughts on European Images of Non-European Man. Baudet spells out two basic and antithetical tendencies that define the ambiguity of the West regarding others and outsiders. One is political; here, "the military, socio-economic, and missionary strategies loom large. These modes mark the concrete relationships that the West establishes with others". The other tendency is that of the "imagination; it is the domain of images and symbols formed of the indigenous cultures outside the West. These imaginative configurations are not derived from concrete relationships; they are not the result of observation, experience, or perceptible reality, but rather have their origin in a psychological urge. Long explains that "the intricate mixture of these two tendencies in the origin and formation of the West enables us to understand how, in the search for new lands - lost utopias and paradises - empirical lands and

\footnotetext{
${ }^{16}$ Abdullah Nasif. (Translator). Eldon Rutter. The Holy Cities of Arabia. Mecca. (Center for the history of Mecca, 2014).

17 Supra note 8.

${ }^{18}$ Charles Long. "A postcolonial meaning of religion: some reflections from the indigenous world: Some reflections from the indigenous world Where is the indigenous located?." In Beyond primitivism, pp. 105-114. Routledge, 2004.
} 
peoples are symbolized and brought within the political and imaginative orbit of the West." Rutter's account on the circumcision is a clear example of such Spivakian othering and Long's psychological urge.

The second extract shows an instance of superiority that is also common in Orientalists' discourse:

I might at heart disagree with the Mekkans in some of their religious practices, but I worshipped the One God, as they did-The God whom Jews, Christians, and Muhammadans worship in common. I had made my prayer with no hope or intention of softening my companions, but now they were my brothers and my servants. The sinister fact of my silence under affliction was now completely erased from their minds.

This contemplation, and confession, by Rutter, is made just after he recovers from a serious illness for which no medicine worked till he relieved himself by reciting a verse from the Quran. Rutter's courtesy of his hosts and caretakers is that they were his "servants". This concept of inferiority of the other no matter how good they were to the writer is evident in most Orientalist writers. Spivak states that "the colonizing subject is created in the same moment as the subaltern subject. In this sense, othering expresses a hierarchical, unequal relationship".

Said reports on a study by Jacques Waardenburg $\left(1970^{19}\right)$ who compared the works of five Orientalists on Islam (Ignaz Goldziher, Duncan Black McDonald, Carl Beker, Snouck Hurgronje and Louis Massignon) and reaches the conclusion that "The manifest differences in their methods emerge as less important than their Orientalist consensus on Islam: latent inferiority." In addition to being a manifestation of a discourse of other inferiority, Rutter's account in this extract and the

\footnotetext{
${ }^{19}$ Jacques Waardenburg, L'Islam dans le miroir de l'Occident .
} 
previous one is an example of a debasement discourse. "Debasement refers to various qualities of the savage (e.g., dishonesty, superstition, lack of self-discipline, irrationality, fanaticism)..health and sanitation problems, unemployment, population growth all are associated with individual filth, indolence, and sexual promiscuity" ${ }^{\prime 20}$. There are other instances in the book where Rutter refers to Arabs short and inaccurate memory (p.166), and to their treachery and wickedness (p. 41). In other instances, he refers to the thieves who tries to steal his money as "the neighbour of God, as the Mekkans are proud to call themselves" (p.41), and a notice on how the people of Yemen "sell their own children" (p.114).

The third extract from Rutter's book is the following:

By the Mekkans, women are most truly esteemed for their ability to bear children, especially male children, and for their success in rearing their offspring safely to the age of puberty. A barren woman, no matter what other excellent attributes or housewifely accomplishments she may possess, seldom retains her husband's affection for any length of time. (vol 1, p.59)

But there are people who own men-slaves and women-slaves; so they let them breed, in order that they may profit by selling the children...like cattle!. (vol 1, p114)

These observations by Rutter concerning women and the status of women, whether free or enslaved, in the early $20^{\text {th }}$ century Arabia are also shocking. If the other is perceived as debased and inferior, women and slaves would be the most debased of the debased, and most destitute of the inferior. Spivak emphasizes

\footnotetext{
${ }^{20}$ Supra note 8 .
} 
the fact that the female subaltern subject is even more peripheral and marginalized than the male. She observes: "If in the context of colonial production, the subaltern has no history, and cannot speak, the subaltern as female is even more deeply in shadow" (p. 28).

This is not to say that women's inferiority in the Arab world is a myth, but rather it is not as presented by Rutter. Syed Hossain Nasr ${ }^{21}$ states:

Within the home Muslim women usually wield great power and authority. In my own very large extended family on both the paternal and maternal side, I have known many mothers who were every bit as powerful and even autocratic as the most forceful "Jewish mother" or "Italian mother." Anyone who thinks that in Islamic society women have always been weak, downtrodden, and oppressed beings simply does not know the inner workings of a Muslim family (p. 19122).

In referring to human cattle breeding, Rutter is drawing again on the exotic discourse of othering, taking into consideration that Slavery in the Ottoman Empire was abolished in 1924 when, according to the encyclopedia of Islam, "the new Turkish Constitution disbanded the Imperial Harem and made the last concubines and eunuchs free citizens of the newly proclaimed republic ${ }^{23}$ ".

\footnotetext{
${ }^{21}$ Seyyed Hossein Nasr. The heart of Islam: Enduring values for humanity. (Zondervan, 2009).

${ }^{22}$ For a detailed discussion on women in Islam, refer to Alexander Knysh. Islam in Historical Perspective. $2^{\text {nd }}$ edition. Routledge, 2017, chapter on women in Islam.

${ }^{23}$ Halil Inalcik, P. Bearman, T. Bianquis, C. Bosworth, E. van Donzel, and W. P. Heinrichs. "The Encyclopaedia of Islam." (1965): 224.
} 
Although women are still suffering in the contemporary Muslim world, they seek strategies for adjustment. Saba Mahmoud ${ }^{24}$, for example, points to the strategies of patience by religious Egyptian young women, and the strategy of self-esteem by liberal young women. One of her interviewees explains that "You practice the virtue of patience [sabr] because it is a good deed, regardless of your situation: whether your life is difficult or happy. In fact, practicing patience in the face of happiness is even more difficult". (p.220). While another one explains, "Self-esteem makes you independent of what other people think of you. You begin to think of your worth not in terms of marriage and men, but in terms of who you really are, and in my case, I draw pride from my work and that I am good at it. Where does sabr get you? Instead of helping you to improve your situation, it just leads you to accept it as fate-passively". (p. 211).

One last extract from Rutter's book shows another instance of latent Orientalism as follows:

Which is the brighter, he says to me; "your moon in Damascus, or this our moon?" Everybody awaits my reply with lazy interest... "The moon is one", I replied. "This moon which we see here is the same moon which the Syrians see, and the Egyptians, and the Indians and all the world. Hassan looked serious but would make no comment. He was unconvinced: I have given him no proof. (p. 35).

In this extract, Rutter is amusing us with a dialogue that showed the stupidity and little mindedness of one Arab. This is one instance of what Said calls "aberrant mentality"; he explains "one of the important developments in nineteenth-century Orientalism was the distillation of essential ideas about the Orient - its sensuality, its tendency to despotism, its aberrant mentality, its habits of

\footnotetext{
${ }^{24}$ Saba Mahmood. "Feminist theory, embodiment, and the docile agent: Some reflections on the Egyptian Islamic
} revival." Cultural anthropology 16, no. 2 (2001): 202-236. 
inaccuracy, its backwardness-into a separate and unchallenged coherence" (p. 205). Focusing on the mental inferiority of the Arabs is much vocal in politician writings, like that of Cromer asking "Can it be any matter for surprise... that the Egyptian, with his light intellectual ballast, fails to see that some fallacy often lies at the bottom of the Frenchman's reasoning?" (Said, p. 212). In the same vein, Curzon once said that "the East is a University in which the scholar never takes his degree" was another way of saying that the East required one's presence there more or less forever. (Said, p. 215). This also represents a discourse of negation, "conceiving of the cultural Other as absence, emptiness, nothingness, negative space, negative history and negative language". (p. $\left.45^{25}\right)$.

\section{Part IV: Still subaltern?}

In this section, we explore instances of contemporary orientalist discourse in the contemporary media coverage of Arabs and Muslims, in a way that shows that Rutter's latent orientalist was even softer than present-day Orientalism. Charles Long ${ }^{26}$ (2004) points out that "for generations of western historians, Europe was both the centre and the standard by which the history of humanity could be measured. According to a simple, linear representation of human development, all societies were thought to pass through identical stages on the path to progress and civilization, with Europe as the most advanced model. In the onward march, non-European societies brought up the rear as examples of less civilized states. Such a view of history provided an ideological justification for Western expansion and world-wide hegemony".(p. 95). Unfortunately, this ideological stand is still active in the contemporary western media coverage of Islam and Muslims.

\footnotetext{
25 Supra note 8

${ }^{26}$ Charles Long, Op.cit.
} 
The term Islam as it is used today seems to mean one simple thing, but in fact, is part fiction, part ideological label, part minimal designation of a religion called Islam. Said ${ }^{27}$ (1997) points out that "Islam today is peculiarly traumatic news in the West. During the past few years, especially since events in Iran caught European and American attention so strongly, the media have therefore covered Islam: they have portrayed it, characterized it, analyzed it, given instant courses on it, and consequently, they have made it known. But this coverage is misleadingly full, and a great deal in this energetic coverage is based on far from objective material. In many instances Islam has licensed not only patent inaccuracy, but also expressions of unrestrained ethnocentrism, cultural, and even racial hatred, deep yet paradoxically free-floating hostility (p. xxi).

For example, in the past, Arabs and Muslims were largely recognized in the West as "erotic", "primitive", "ignorant", "slave traders" among other many derogatory terms. Lately, the terms such as "terrorist", "fundamentalist" and "blood-thirsty" are the terms that are over-generally ascribed to the Arabs and Muslims. As John Esposito ${ }^{28}$ (1992) says, "Fear of the Green Menace [green being the colour of Islam] may well replace that of the Red Menace of world communism. ... Islam is often equated with holy war and hatred, fanaticism and violence, intolerance and the oppression of women" (p.203).

For more than a century, movies have dramatized myth-making. Ever since the camera began to crank, the unkempt Arab has appeared as an uncivilized character, the cultural

\footnotetext{
${ }^{27}$ Edward Said. Covering Islam: How the Media and the Experts Determine How We See the Rest of the World. (Vintage Books. 1997).

${ }^{28}$ John Esposito. The Islamic Threat. (New York: Oxford University Press, 1992). P.203
} 
Other, someone who appears and acts differently than the white Western protagonist, someone of a different race, class, gender or national origin. Driss Ridouani ${ }^{29}$ (2011) explains that

The diverse Islamic world is populated solely with bearded mullahs, shady sheikhs in their harems, bombers, backward Bedouin, belly dancers, harem maidens and obsequious domestics. Image makers cover women in black from head to toe and have them follow several paces behind abusive sheikhs, their heads lowered, as mute, uneducated, unattractive, enslaved beings, solely attending men. (p.4).

In conjunction with the Western media's target to disdain Arab's literature and writings in general, Walt Disney's famous animated cartoon Aladdin delineates Arabs in a negative way. Despite the story deals with an Arab cultural background, the cartoon of Aladdin, is so worked up that it looks more American than Arab. It does not only Americanize the characters' names, but it also westernizes their appearances. Badr Al Bodour whose name changed by Walt Disney into Jasmine, had her clothes also undergone a radical change; her attire makes her look more like a "belly-dancer" than a princess. Hence, instead of preserving her royal chastity and nobility hence her true identity, she seems sexy in her traditional dress.

Jack Shaheen $^{30}$ (1990) cogently summarizes the stereotypical and overstated images of Arabs in the Western motion pictures: "Hollywood's sheikh of the 1920 s became the oily sheikh of the 1970s and 1980s, and now the fanatical "fundamentalist" terrorist who prays before killing innocents. Today's sheikhs are uncultured and ruthless, attempting to procure media conglomerates (Network, 1977), destroy the world's economy (Rollover, 1981), kidnap Western women (Jewel of

\footnotetext{
${ }^{29}$ Driss Ridouani. "The representation of Arabs and Muslims in Western media." RUTA Comunicación 3 (2011). P.4
}

30 Jack Shaheen. "Our Cultural Demon: The 'Ugly' Arab," Washington Post, August 19, 1990, pp. C1, C2. 
the Nile, 1985), direct nuclear weapons at Israel and the United States (Frantic, 1988), and influence foreign policies (American Ninja 4: The Annihilation, 1991).

\section{Conclusion:}

Antonio Gramsci was the first to use the term "subaltern" to refer to social groups under the hegemonic control of the ruling elite. In this sense, the term can refer to any group that is collectively subordinated or disenfranchised, whether on the basis of race, ethnicity, sex, religion, or any other category of identity ${ }^{31}$. Spivak's theory of subaltern studies works finely to interpret the power relation between the hegemonic west and the formerly colonized Muslim world. Esposito (1990) explains that "Muslims are lumped together, and our expectations are based more on stereotyping than on empirical research". All too often the "coverage of Islam and the Muslim world concludes there is a monolithic Islam out there somewhere, believing, feeling, thinking and acting as one." Ridouani (2011) sees that the "stereotypical Muslim presented to Americans resembles Iran's Ayatollah Khomeini, Libya's Moammar Gadhafi, or Iraq's Saddam Hussein; the imagery "has profoundly affected American perceptions of Islam and the Middle East". Despite the different races that are included under the banner of Islam (Arabs, Persians, Asians etc.), in view of the West all Muslims are Arabs. In other words, far from being a multicultural, multiracial, and multiethnic groups, Muslims are stereotypically embodied in one persona which is characterized by all sorts of devilish deeds.

At the end of Spivak's significant article, she answers the question posed in the title by "the subaltern can not speak...representation has not withered away". (p.104). If the subaltern can

\footnotetext{
$31{ }^{31}$,Hagai Katz. "Gramsci, hegemony, and global civil society networks." Voluntas: International Journal of Voluntary and Nonprofit Organizations 17, no. 4 (2006): 332-347.
} 
speak, they would no longer be subaltern. With the dramatic effects of media prejudiced discourse resulting in terrorist acts like the recent one in New Zealand 2019, I remain apprehensive whether the subaltern can yet be listened to.

\section{Bibliography:}

Deal, William and Timothy Beal. Theory for religious studies. London: Routledge, 2004. Esposito, John. The Islamic Threat. New York: Oxford University Press, 1992.

Gibb, Hamilton. Review of The Holy Cities of Arabia by Eldon Rutter, Bulletin of the School of Oriental and African Studies, 51929.

Halil, Inalcik, P. Bearman, Th Bianquis, C. E. Bosworth, E. van Donzel, and W. P. Heinrichs. "The Encyclopaedia of Islam." 1965.

Katz Hagai. "Gramsci, hegemony, and global civil society networks." Voluntas: International Journal of Voluntary and Nonprofit Organizations 17, no. 4 (2006): 332-347.

Knysh, Alexander. Islam in Historical Perspective. $2^{\text {nd }}$ edition. Routledge, 2017.

Long Charles. "A postcolonial meaning of religion: some reflections from the indigenous world: Some reflections from the indigenous world Where is the indigenous located?." In Beyond primitivism, pp. 105-114. Routledge, 2004.

Mahmood, Saba. "Feminist theory, embodiment, and the docile agent: Some reflections on the Egyptian Islamic revival." Cultural anthropology 16, no. 2 (2001): 202-236

Nasif, Abdullah. (Translator). Eldon Rutter. The Holy Cities of Arabia. Mecca. Center for the history of Mecca, 2014.

Nasr, Seyyed Hossein. The heart of Islam: Enduring values for humanity. Zondervan, 2009.

Ridouani, Driss. "The representation of Arabs and Muslims in Western media." RUTA Comunicación 3, 2011.

Rutter, Eldon. The Holy Cities of Arabia. London and New York. Putnam's sons, 1928.

Said, Edward. Covering Islam: How the Media and the Experts Determine How We See the Rest of the World. Vintage Books, 1997.

Said, Edward. Orientalism Reconsidered. Cultural Critique, No. 1 Autumn, 1985, pp. 89-107

Said, Edward. Orientalism. Vintage Books, 1994. 
Schacht, Joseph. "Eldon Rutter: The Holy Cities of Arabia". Book review. Journal Orientalistische Literaturzeitung; Jan 1, 1930; 33, Periodicals Archive Online pg. 213

Shaheen, Jack. "Our Cultural Demon: The 'Ugly' Arab," Washington Post, August 19, 1990, pp. $\mathrm{C} 1, \mathrm{C} 2$.

Shipman, John. "Eldon Rutter. The Holy Cities of Arabia." Book Review. Asian Affairs, 47:1, 141-143, DOI: 10.1080/03068374.2016.1130966 (2016): 141-143.

Spivak, Gayatri Chakravorty. "Can the Subaltern Speak?". In The post-colonial studies reader. Edited by Ashcroft, Bill, Gareth Griffiths, and Helen Tiffin, eds. Taylor \& Francis, 2006.

Spurr, David. "The Rhetoric of Empire: Colonial Discourse in Journalism, travel writing and imperial administration. Duke University Press, 1993.

Waardenburg, Jacques L'Islam dans le miroir de l'Occident .

Wolfe, Michael. One Thousand Roads to Mecca: Ten Centuries of Travelers Writing about the Muslim Pilgrimage. New York: Grove Press, 1997. 